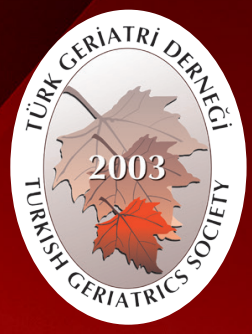

Turkish Journal of Geriatrics DOI: $10.31086 /$ tjgeri.2018.56 2018;21 (4):515-521

- Arzu KARAVELi1

- Galip Neşet CERIT'1

- Erhan ÖZYURT'1

\title{
EVALUATION OF ADMISSION CAUSES AND MORTALITY RATES OF 65 YEARS OF AGE AND OLDER PATIENTS ADMITTED FROM THE EMERGENCY DEPARTMENT TOTHE INTENSIVE CARE UNIT
}

\section{Abstract}

Introduction: With increasing life expectancy, admission of elderly patients to intensive care units is increasing. We aimed to determine profiles, admission causes and mortality rates of elderly patients who were admitted from the emergency department to the intensive care unit. Because the cost of intensive care hospitalisation is high, this data may be important when determining elderly patients health policies.

Materials and Method: This retrospective study included elderly patients who were admitted from the emergency department to the intensive care unit. The patients' age, sex, chronic illnesses, date of admission, admission causes and mortality rates were recorded.

Results: The mean age of the elderly patients was 76.19 years, $53.4 \%$ of the patients were males, and $70.3 \%$ of the total patients had $\geq 1$ chronic diseases. The most frequent chronic disease was hypertension. The most common cause of admission was cardiovascular disease. The frequency of myocardial infarction was equally high in male and female patients. They were mostly admitted to the coronary intensive care unit. Intensive care unit admissions were mostly noted during winter. The mortality rate was $14.75 \%$.

Conclusion: With the increasing population of elderly people because of increased life expectancy, the admission of elderly patients to the intensive care units is gradually increasing. The intensive care unit hospitalisation cost and mortality rate of elderly patients' is high. Taking all of this into account, identifying admission causes and mortality rates of elderly patients will provide guidance for the approach used for their diagnosis and treatment and for determining medical policies.

Keywords: Aged; Patient; Intensive care unit; Mortality; Emergency department

CORRESPONDANCE

\section{Arzu KARAVELI}

University of Health Sciences, Antalya Training

and Research Hospital, Department of

Anesthesiology and Reanimation, Antalya, Turkey

Phone: 5325611300

e-mail: arzukaraveli@hotmail.com

Received: 04/09/2018

Accepted: 02/11/2018

University of Health Sciences, Antalya Training and Research Hospital, Department of Anesthesiology and Reanimation, Antalya, Turkey
ARASSTIRMA

\section{ACIL SERVISTEN YOĞUN BAKIM ÜNITESINE KABUL EDILEN 65 YAŞ VE ÜZERI HASTALARIN KABUL NEDENLERI VE MORTALITE DEĞERLERININ DEĞERLENDIRILMESI $\ddot{O}_{z}$}

Giriş: Yaşın ilerlemesi ile birlikte, yoğun bakım ünitelerine yaşlı hastaların kabulü de artmaktadır. Bu çalışmada, acil servisten yoğun bakım ünitelerine kabul edilen yaşlı hastaların profilleri, başvuru nedenleri ve mortalite oranlarının belirlenmesi amaçlanmıştır. Yoğun bakım yatışların maliyetlerinin yüksek olduğunu dikkate alındığında, bu verilerin yaşlı hastaların sağlık politakasını belirlemede önemli olabileceğini düşünmekteyiz.

Gereç ve Yöntem: Bu retrospektif çalışma, acil servisten yoğun bakım ünitelerine kabul edilen yaşlı hastalarda yapıldı. Hastaların yaşı, cinsiyeti, kronik hastalıkları, başvuru tarihleri, ve mortalite oranları kaydedildi.

Bulgular: Yaşlı hastaların yaş ortalaması 76.19yıldı ve \%53.4'ü erkekti. Bunların \%70.3'ünde bir veya daha fazla kronik hastalık vardı. En sık görülen kronik hastalık hipertansiyondu. En sık başvuru nedeni kardiyovasküler hastalıklardı. Myokardiyal infaktüs sıklığı hem erkek hem de kadın hastalarda yüksekti. Hastalar sıklıkla koroner yoğun bakım ünitesine kabul edildi. Yoğun bakım ünitesine başvuru sıklıkla kış aylarındaydı. Mortalite oranı \%14.75'di.

Sonuç: Yaşlı nüfusun artışı ile birlikte, yaşlı hastaların yoğun bakım ünitelerini kullanım oranı her geçen gün artmaktadır. Yaşlı hastaların yoğun bakım maliyetleri ve mortalite oranları çok daha yüksektir. Tüm bunlar dikkate alındığında, yaşlı hastaların yoğun bakım ünitesine kabul nedenleri ve mortalite oranlarının belirlenmesi, bu hastaların tanı ve tedavi yaklaşımlarına ve sağlık politikalarının belirlenmesine rehberlik sağlayacaktır.

Anahtar sözcükler: Yaşlı; Hasta; Yoğun bakım ünitesi; Mortalite; Acil servis 


\section{INTRODUCTION}

Old age and the ageing process, which are important in developed countries, have been gaining increasing importance in developing countries, such as Turkey (1). The elderly population is gradually increasing worldwide because of the increasing life expectancy and decreasing birth rate. According to data of $2016,8.7 \%$ of the total world population is elderly ( $\geq 65$ years old). In Turkey, according to data of the Turkey Statistics Institute reported in 2016, the number of elderly has increased by $17.1 \%$ in the last 5 years, and the proportion of the elderly has reached to $8.3 \%$ of the population by the end of 2016 (2). Consistent with this increase in the elderly population, the rate of admission of elderly patients to hospitals, particularly to emergency departments (EDs) and intensive care units (ICUs), is also gradually increasing (3-7). Admission rates of elderly patients are variable in different countries, cities and regions (4). In addition, the admission rates of elderly patients to EDs vary according to the population and socioeconomic status of the elderly in the city; location and total number of hospitals in the city and characteristics of the hospital, such as bed capacity $(5,8)$. According to a study by Strange et al., in a total of 70 hospitals in 25 states, elderly patients are 5.6 times more likely to be admitted to the hospital than younger patients and almost $15 \%$ of the patients admitted to EDs are elderly (9). As reported in the literature, the admission rates of elderly patients to EDs vary from $9 \%$ to $19 \%(3,9)$. Elderly patients are more likely to suffer from chronic diseases, multiple drug usage and more complex symptoms (7); they require more laboratory tests to confirm their diagnosis and longer stays in hospital and ICUs than non-elderly patients (10).

It has been observed that elderly patients are admitted to ICUs 2.5-4.6 times more frequently than younger patients (5). Approximately half of the patients admitted to ICUs in the United States are reported to be elderly (11).

In this study, it was aimed to determine profiles, admission causes and mortality rates of geriatric patients who were admitted from EDs to ICUs. Because the ICU hospitalisation cost of geriatric patients' is much higher, having information on their admission causes to ICUs and mortality rates can be of significant guidance when determining health policies.

\section{MATERIALS AND METHOD}

This was a retrospective observational study of $\geq 65$-year-old patients who were admitted from EDs to ICUs of the University of Health Sciences Antalya Education and Research Hospital between 1 January and 31 December 2015. The study was approved by the ethics committee of the hospital (76/15). Patients' age, sex, chronic illnesses, date of admission to EDs (day, season and year), causes of hospitalisation, ICU type (coronary, reanimation, neurology, etc.) and mortality rates in ICUs were recorded. In patients with recurrent ICU admission, the first admission of the patient was considered for analysis. Hospitalisation causes for admission of patients to ICUs were grouped according to ICD 10 codes in the 'SARUS' hospital information system used in our hospital. In this study, the seasons were defined as follows: spring: $1^{\text {st }}$ March-31 st $^{\text {st }}$ ay, summer: $1^{\text {st }}$ June $-31^{\text {st }}$ August, autumn: $1^{\text {st }}$ September $-30^{\text {th }}$ November and winter: $1^{\text {st }}$ December-28 ${ }^{\text {th }}$ February.

Obtained data were analysed using Statistical Package for Social Sciences for Windows 23.0. Descriptive data are summarised in frequency (n), percentage (\%) and mean \pm standard deviation. Continuous and categorical variables were compared using the chi-square test. $p$ values of $<0.05$ were accepted as statistically significant. 


\section{RESULTS}

Between 1 January 2015 and 31 December 2015, 1.200 elderly patients were admitted from EDs to ICUs. The mean age of these patients was $76.19 \pm 7.4(65-104)$ years, and $53.4 \%$ of them were males.

Further, $70.3 \%$ of the elderly patients had $\geq 1$ chronic disease. Regardless of the chronic disease association, the six most frequent chronic diseases in elderly patients were hypertension (HT) (44.8\%), coronary artery disease (CAD) (43.2\%), hyperlipidaemia (31.1\%), congestive heart failure (12.3\%), diabetes mellitus (DM) (10.3\%) and chronic obstructive pulmonary disease (COPD) (4.4\%). The most common cause of admission to ICUs was myocardial infarction.

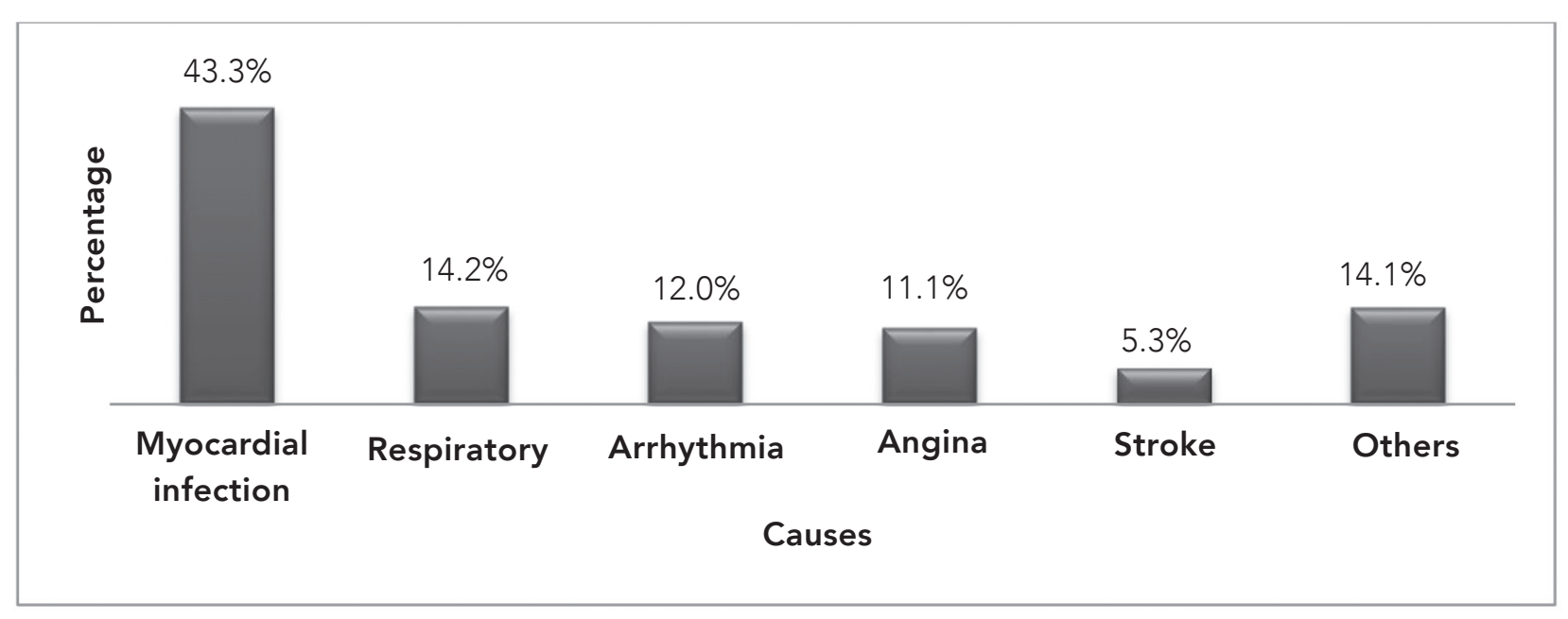

Figure 1. Causes of ICU hospitalisation.

The distribution of patients according to ICU admission causes is shown in Figure 1. When admission causes were analysed by gender, myocardial infarction was found to be the most frequent cause in male and female patients. The second most frequent cause was respiratory system disorders in males and arrhythmia in females $(p<0.05)$.

When ICU admissions of elderly patients were evaluated in terms of the ICU type, the most frequent admission was in the coronary ICU (74.3\%). The rates of patients admitted to each ICU type are shown in Figure 2.

ICU admissions were most frequently noted during winter (Figure 3). However, no statistically significant difference was observed between seasons and admission causes ( $p>0.05$ ). 


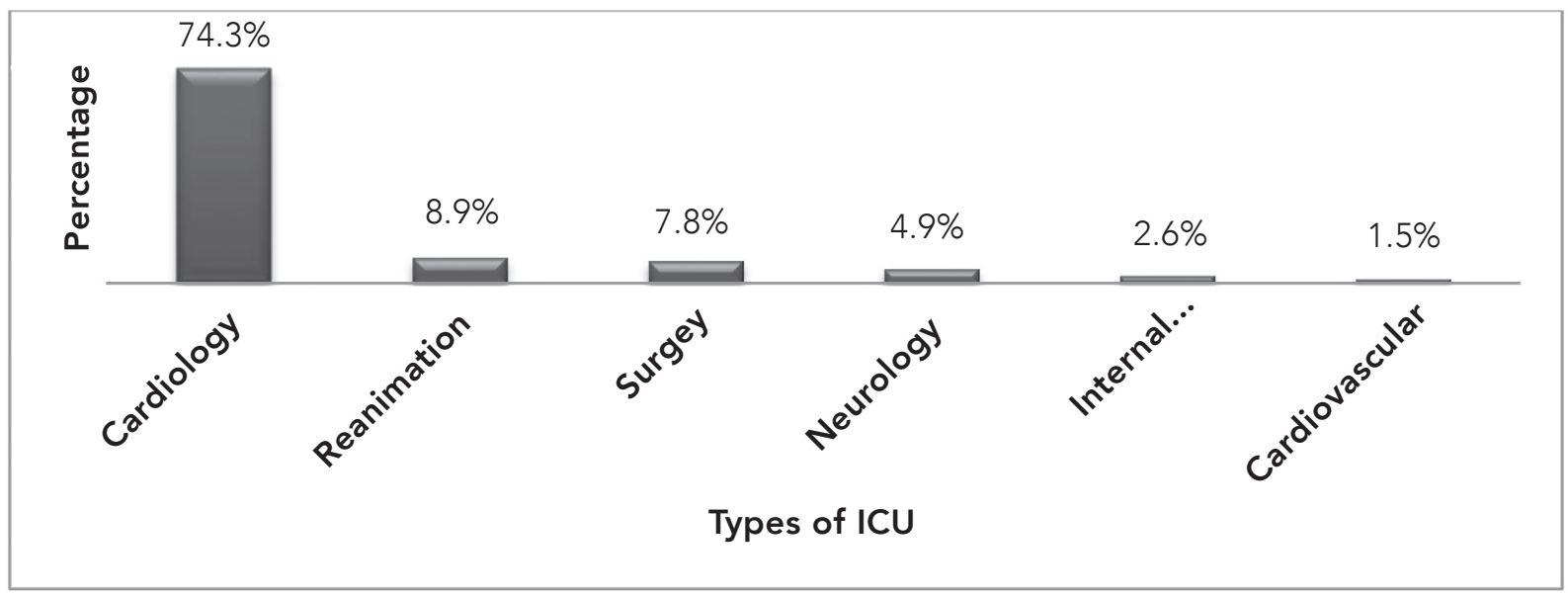

Figure 2. Admission rates of elderly patients from EDs to ICUs.

The most frequent admission causes to each ICU department were determined to be myocardial infarction to cardiology ICU, respiratory problems to reanimation and surgery ICUs, stroke to neurology $I C U$, other causes (such as gastric bleeding and electrolyte imbalance) to internal medicine ICU and aortic dissection to cardiovascular surgery ICU. The mortality rate in the ICU of the patients admitted from ED to ICU was $14.75 \%$.

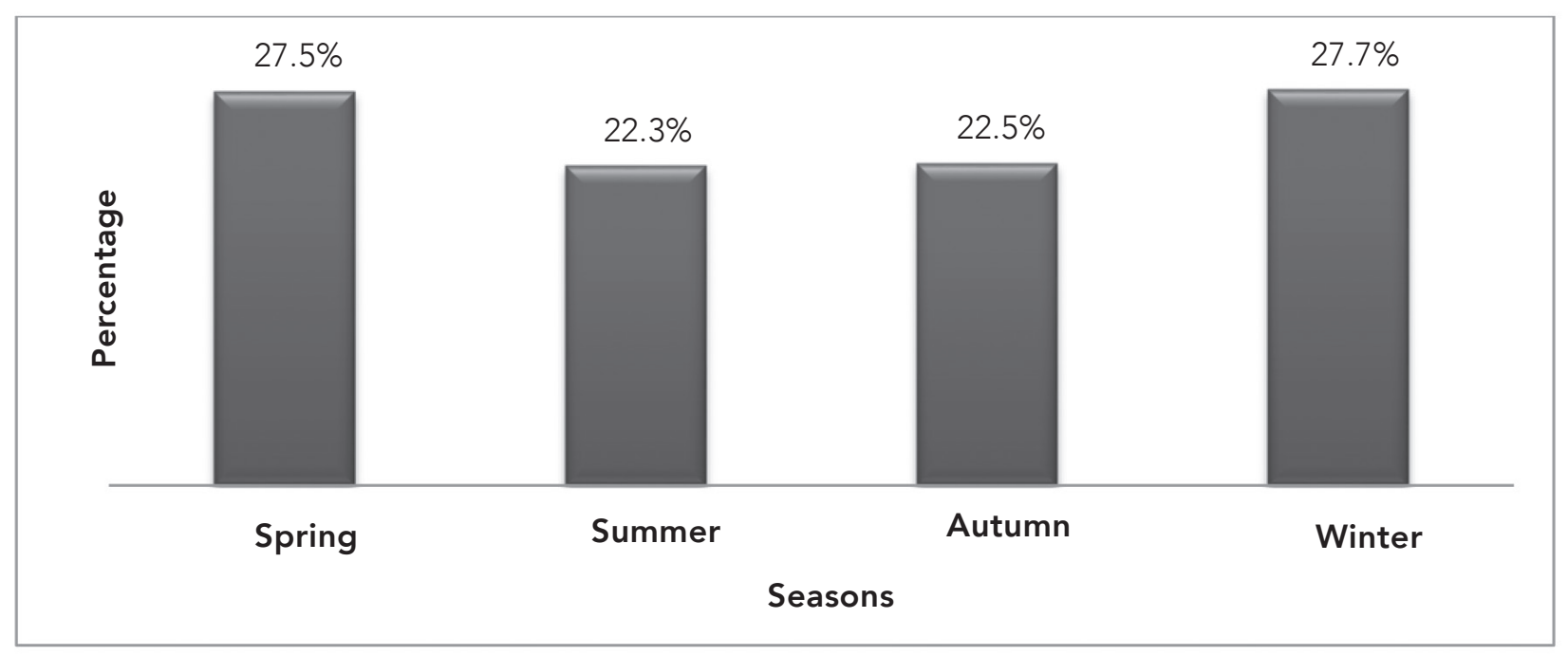

Figure 3. Seasonal changes in the admission rates of elderly patients. 


\section{DISCUSSION}

The elderly population requires more intensive care than the younger population because of physiological changes and chronic diseases that occur because of ageing (5). Ozdemir et al. evaluated the chronic disease prevalence and risk factors in the elderly and found that $78 \%$ of elderly patients ( $\geq 65$ years old) have at least one chronic disease (12).

It is suggested that $90 \%$ of the elderly have at least one chronic disease, 35\% have two chronic diseases 23\% have three chronic diseases and 15\% have $\geq 4$ diseases (4). Consistent with these findings, we found that $70.3 \%$ of the elderly patients who were admitted from EDs to ICUs had at least one chronic disease, and regardless of the coexistence of chronic diseases, the most frequent chronic disease was cardiovascular disease, particularly HT. In a similar study, Laloglu et al. found that cardiovascular diseases, particularly HT and CAD, are the most frequently observed diseases in elderly patients, followed by DM and respiratory diseases, such as asthma/COPD (4). Consistent with our findings, one study conducted in Italy reported that HT and cardiovascular diseases are the most frequently occurring diseases in the geriatric population, but contrary to our findings, it also reported that anaemia and cerebrovascular diseases were the second and third most frequent diseases, respectively (13). Taymaz et al. showed that an average of $2.95 \pm 1.82$ comorbidities occurred in elderly patients, and their evaluation revealed that cardiovascular diseases, particularly HT, were most commonly observed, followed by DM and respiratory diseases; this was consistent with our findings (14). According to the findings of the Turkish Hypertension Prevalence study in 2003, the prevalence of HT increases with age and reaches $70 \%-80 \%$ at $\geq 60$ years of age (15).

Admission rates of elderly patients from EDs to ICUs may vary seasonally between countries, cities and even regions. A study evaluating the seasonal variations in admissions to EDs in Mersin, Turkey, found that the admission rates increased during summer (16). Another study conducted in Adana showed that admission rates to EDs increased during winter (8). Baz et al. found that the highest rate of admission in Mardin was during autumn (17). Literature states that hospital admissions of patients with cardiovascular diseases show seasonal variation (18). In the study by Satar et al., heart failure was more frequently observed during spring than during other seasons, whereas respiratory diseases were more frequent during winter (8). Another study found that respiratory system disorders and acute bronchitis were more frequent during winter and stroke was more frequent during autumn (17). In our study, although elderly patients were more likely to be admitted to ICUs than younger patients, significant seasonal changes were not observed. This may be due to different socio-cultural structures and locations of the hospitals. Our hospital serves as a reference hospital in the centre of Antalya.

In our study, $53.4 \%$ of the elderly patients who were admitted from EDs to ICUs were males. Conversely, literature states that the proportion of females in the population and their life expectancy are higher, which also results in higher admission rates for elderly females $(3,17)$. However, considering that cardiovascular diseases, particularly ischaemic heart disease and heart failure, and hospitalisation because of cardiovascular diseases are more prevalent in males (19), the admission rates to ICUs may be higher in males than in females. In a study investigating intensive care experiences of elderly patients, more than half of the patients were males (6).

Many studies have been conducted on the causes of admission of elderly patients to EDs. Elderly patients were admitted most frequently because of HT and cardiac and pulmonary diseases in the study by Unsal et al. (3); because of stroke in the study by Satar et al. (8); because of metabolic/ systemic diseases and cardiovascular and cerebrovascular problems in the study by Kekec et al. (20); because of cardiac problems, such as chest pain, HT and acute coronary syndrome, in the 
study by Mert et al. (16); because of cardiovascular problems in the study by Baz et al. (17) and because of cardiovascular and respiratory problems in the study by Akpinar et al. (21). In our study, elderly patients were most frequently admitted because of cardiovascular diseases.

Differences among the studies may be due to different socio-cultural structures which each hospital serves, locations of the hospitals and characteristics of the hospital. Unlike other studies, in our study, causes of admission from EDs to ICUs were considered. In the study of $\mathrm{Yu}$ et al. on ICU uses and mortalities in the elderly, patients with cardiac diagnoses, such as congestive heart failure, myocardial infarction, angina pectoris and arrhythmia, were found to be frequently admitted to ICU (22). Most patients admitted to EDs and those hospitalised are most frequently followed up in a clinic. Depending on the severity of the underlying disease, only a small proportion of patients are admitted to ICUs after ED admission. Literature states that elderly patients are hospitalised 2.5-4.6 times more frequently and are admitted to ICUs 5.5 times more frequently than younger patients (9), indicating that elderly patients have higher admission rates to ICUs than younger patients (5). Laloglu et al. found that elderly patients who were admitted to the ED had a hospitalisation rate of $21.1 \%$ and that only $34.6 \%$ of them were subsequently admitted to the ICU (4). In one study, Kekec et al. found that the hospitalisation rate of elderly patients in the ED was $61.1 \%$ and that $38.1 \%$ of them were transferred to the ICU (20). In a study by Baz et al., the hospitalisation rate of elderly patients was $11.5 \%$; $13.6 \%$ of these patients were monitored in the ICU (17). Further, the hospitalisation rate of elderly patients was $59.35 \%$ in a study by Satar et al.; $70.4 \%$ of these patients were admitted to the ICU (8). When considering the fact that the incidence of chronic diseases increased with age, cardiovascular and respiratory problems are more frequent and fatal in elderly patients and hospitalisation rates and durations are higher in elderly patients than in younger patients (14), we believed that elderly patients are more frequently admitted to ICUs with cardiovascular problems, such as $\mathrm{Ml}$; arrhythmia and respiratory problems, such as COPD.

The mortality rate of elderly patients is higher due to the severity of the underlying diseases (1). In our study, the mortality rate was $14.75 \%$ in elderly patients admitted from EDs to ICUs, and cardiac problems were the most frequent causes of mortality. In the study by Baz et al., the highest mortality rate was observed for elderly patients hospitalised to ICUs, and the most frequent causes of mortality were cardiac problems (17).

For patients aged between 18 and 70 years in the ICU, on an average, there is a $1 \%$ increase in the mortality for all patients. For those aged $>70$ years, the rate of increase in the mortality becomes $2 \%$ for all patients. The 6-month expected mortality rate is $44 \%$ for 55 -year-old patients, $48 \%$ for 65 -year-old patients, 53\% for 75 -year-old patients and $60 \%$ for 85 -year-old patients (23). According to the study by Topeli et al., the hospital mortality rate of $>65$-yearold patients was much higher than that of $<65$-yearold patients (from $54.9 \%$ to $35.4 \% ; p<0.01$ ). This hospital mortality rate also continues to be high after the hospital term for the same age group (24).

Our study has some limitations. Our study was based on retrospective file scanning, involved a single centre and evaluated only the first admission of the elderly patients. Because the number of admissions and causes of hospitalisation may vary according to the characteristics of hospitals, seasons and regions, it is not possible to generalise our results.

In our study, we found that cardiac diseases were the most frequent admission and mortality causes in elderly patients who were admitted from EDs to ICUs. We also observed that elderly patients were most frequently admitted to the cardiology ICU. Chronic diseases in elderly patients, health spending and the problems faced in ICUs will provide opportunities for more rational use of 
medical policies, which also includes end-of-life decisions and palliative treatment. We believe that the health policies of elderly patients should be redetermined based on this and similar study results.

\section{REFERENCES}

1. Akpinar O, Turkdogan KA, Kapci M, Duman A. Use of emergency department by geriatric patients. J Clin Anal Med 2015;6:310-4.

2. Altun B, Arici M, Nergizoglu G, et al. Prevalence, awareness, treatment and control of hypertension in Turkey (the PatenT study) in 2003. J Hypertens 2005;23(10):1817-23. (PMID:16148604).

3. Baz U, Satar S, Kozaci N, Acikalin A, Gulen M, Karakurt U. Geriatric patient admissions to emergency service. JAEM 2014;13:53-7.

4. Demircan A, Bikmaz SGA, Kadi G, et al. Evaluation of the general characteristics of patients aged 85 years and above admitted to a university hospital emergency department. Turk J Med Sci 2017;47:1393-402. (PMID:29151309).

5. Hamel MB, Davis RB, Teno JM, et al. Older age, aggressiveness of care and survival for seriously ill, hospitalized adults. Ann Intern Med 1999;131(10):7218. (PMID:10577294)

6. İsezuo SA. Seasonal variation in hospitalisation for hypertension related morbidities in Skoto, north-western Nigeria. Int J Circumpolar Health 2003;62(4):397-409. (PMID:14964766).

7. Kekec Z, Koc F, Buyuk S. Review of geriatric patients hospitalization in emergency department. JAEM 2009;8(3):21-4.

8. Laloglu A, Ayrik C, Kose A, et al. Analysis of non-traumatic elderly patient presentations to the emergency department. $\mathrm{Tr} \mathrm{J}$ Emerg Med 2013;13(4):171-9.

9. Marengoni A. Patterns of chronic multimorbidity in the elderly population. J Am Geriatr Soc 2009;57:22530. (PMID:19207138).

10. Mert E. Use of emergency departments by elderly patients. Turk J Geriatrics 2006;9(2):70-4. (in Turkish).

11. Ozdemir L, Koçoglu G, Sumer H, et al. Frequency of some chronic diseases and risk factors among the elderly people in Sivas, Turkey. Cumhuriyet Med J 2005;27:89-94.

12. Ozşaker E, Alcan OA, Korkmaz DF. Investigation of intensive care experiences of the elderly patients. Turk J Geriatrics 2013;16(4):408-13.

\section{Conflict of interest}

The authors have no conflict of interest to declare.

13. Republic of Turkey Ministry of Health. Turkish Public Health Institution. Turkey healthy ageing action plan and implementation program 2015-2020. [Internet] Available from: http://www.nationalplanningcycles. org/sites/default/files/planning_cycle_repository/ turkey/turkey_health_ageing_action_plan_ and_implementation_program_2015-2020.pdf. Accessed: 01.07.2018.

14. Samaras N, Chevalley T, Samaras D, Gold G. Older patients in the emergency department: a review. Ann Emerg Med 2010;56:261-9. (PMID:20619500).

15. Satar S, Sebe A, Avci A, Karakus A, İcme F. Emergency department and the elderly patient. Cukurova Med J 2004;29:43-50.

16. Strange GR, Chen EH, Sanders AB. Use of emergency departments by elder patients: Projections from a multicenter data base. Ann Emerg Med 1992;21:819-24. (PMID:1610039).

17. Taymaz T. Examination of geriatric patients hospitalised from the emergency department. Journal of Academic Geriatrics 2010;2(3):167-75. (in Turkish).

18. Topeli A. Elderly patient in the intensive care unit. Turk J Geriatrics 2000;3(4):151-4. (in Turkish).

19. Topeli $A$. The outcome of the geriatric patients in the ICU. Crit Care 2005;5(1):P249.

20. Turkish Statistical Institute. Elderly statistics, 2016. [Internet] Available from: http://www.turkstat.gov.tr/ PreHaberBultenleri.do?id=24644. Accessed: 01.07.2018.

21. Ulger Z, Cankurtaran M. Elderly patient in intensive care units. Turkish J Int Care Med 2006;6(2):94-100.

22. Unsal A, Cevik AA, Metintas S, Arslantas D, İnan OÇ. Emergency department visits by elder patients. Turk J Geriatrics 2003;6(3):83-8. (in Turkish).

23. Ye F, Piver WT, Ando M, Portier CJ. Effects of temperature and air pollutants on cardiovascular and respiratory diseases for males and females older than 65 years of age in Tokyo, July and August 1980-1995. Environ Health Perspect 2001;109:355-9. (PMID:11335183).

24. Yu W, Ash AS, Levinsky NG, Moskowitz MA. Intensive care unit and mortality in the elderly. J Gen Intern Med 2000;15:97-102. (PMID:10672112). 